\title{
The Influence of Intermolecular Interactions between Maleic Anhydride, Cellulose Nanocrystal, and Nisin-Z on the Structural, Thermal, and Antimicrobial Properties of Starch-PVA Plasticized Matrix
}

\author{
Taíla V. de Oliveira ${ }^{1, *}$, Pedro A. V. de Freitas ${ }^{1}$, Cicero C. Pola ${ }^{2} \mathbb{D}$, Larissa R. Terra ${ }^{3}$, José O. R. da Silva ${ }^{1}$, \\ Amanda T. Badaró ${ }^{4}$, Nelson S. Junior ${ }^{1}$, Marciano M. de Oliveira ${ }^{4}$, Rafael R. A. Silva ${ }^{1}$ D and Nilda de F. F. Soares ${ }^{1}$ \\ 1 Food Packaging Laboratory, Food Technology Departament, Federal University of Viçosa, \\ Viçosa 36570-900, Brazil; pedroafreitas3@gmail.com (P.A.V.d.F.); joseosvaldobm@gmail.com (J.O.R.d.S.); \\ soaresnelson0@gmail.com (N.S.J.); rafaelmega@yahoo.com.br (R.R.A.S.); nfsoares10@gmail.com (N.d.F.F.S.) \\ 2 Nanoscale Biological Engineerign Laboratory, Iowa State University, Ames, IA 50011, USA; \\ cicerocp@iastate.edu \\ 3 Theorical and Applied Chemometrics Laboratory, Chemistry Institute, University of Campinas, \\ São Paulo 13083-970, Brazil; larissarochaterra@gmail.com \\ check for \\ updates \\ 4 School of Food Engineering, University of Campinas, São Paulo 13083-970, Brazil; \\ tbadaro.amanda@gmail.com (A.T.B.); oliveira.ealufv@gmail.com (M.M.d.O.) \\ * Correspondence: taveloso@icloud.com; Tel.: +55-(31)-3899-1756
}

Citation: Oliveira, T.V.d.; Freitas, P.A.V.d.; Pola, C.C.; Terra, L.R.; Silva, J.O.R.d.; Badaró, A.T.; Junior, N.S.; Oliveira, M.M.d.; Silva, R.R.A.; Soares, N.d.F.F. The Influence of Intermolecular Interactions between Maleic Anhydride, Cellulose Nanocrystal, and Nisin-Z on the Structural, Thermal, and Antimicrobial Properties of Starch-PVA Plasticized Matrix. Polysaccharides 2021, 2, 661-676. https://doi.org/10.3390/ polysaccharides 2030040

Academic Editor: Rajkumar Patel

Received: 15 June 2021

Accepted: 2 August 2021

Published: 10 August 2021

Publisher's Note: MDPI stays neutral with regard to jurisdictional claims in published maps and institutional affiliations.

Copyright: (c) 2021 by the authors. Licensee MDPI, Basel, Switzerland. This article is an open access article distributed under the terms and conditions of the Creative Commons Attribution (CC BY) license (https:/ / creativecommons.org/licenses/by/ $4.0 /)$.

\begin{abstract}
On behalf of a circular economy, regular plastics have been replaced by biodegradable packagings. Besides, active films have been applied to improve the shelf-life and quality of foods. In this work, blends were developed using starch as a low-cost natural polymer, mixed with poly(vinyl alcohol) due to its physical-chemical and biodegradable properties. Moreover, maleic anhydride (MaAh), cellulose-nanocrystal $(\mathrm{CN})$, and nisin-z (N-Z) were added, respectively, as a compatibilizer, a mechanical-reinforce, and antimicrobial agents. The thermal stability of the films was analyzed, which blends' melting temperature occurred around $200-207^{\circ} \mathrm{C}$, and it was influenced by CN, N-Z, and MaAh amounts. N-Z and MaAh acted against S. aureus and P. aeruginosa by compound diffusion (inhibition-halo around 1.85 and $2.18 \mathrm{~cm}$ ); while $S$. Choleraesuis and E. coli were inhibited by contact. Therefore, these blends presented the potential to be used as active biodegradable packaging in the food industry.
\end{abstract}

Keywords: active packaging; biodegradable blends; intermolecular interactions; thermal stability

\section{Introduction}

In order to solve the problems generated by plastic waste, environmental concerns have given rise to demands for novel biodegradable polymers and friendly materials, mainly for applications related to food packaging [1,2]. Most of the research focuses on substituting petro-based plastics with biodegradable materials that contain similar properties at a low cost [2].

Natural polymers often do not have the required features to replace synthetic plastics. One of the ways to address the issue is a chemical modification of the biopolymers, but such changes can lower their environmental friendliness. Another option, using more simple technologically that is also cost-effective, is blending them with other biodegradable polymers for composite material formations [3].

Among natural polymers, starch has been considered one of the most promising substances to produce biodegradable films because of its attractive combination of abundance and thermoplastic behavior [2]. However, high crystallinity and several hydrogen bonds result in poor processability, which became the most significant limiting factor for starch films [3,4]. Poly(vinyl alcohol) (PVA) is a polar biodegradable synthetic polymer that 
exhibits high tensile strength, flexibility, and excellent film-forming characteristics, and ideal features to produce polymer blends [3,5]. Besides that, the addition of compatibilizer compounds into a polymer matrix, such as maleic anhydride, has been used to improve the interfacial adhesion between polymers $[6,7]$.

A composite material can be more complex than only the polymer matrix since many more substances can be incorporated to improve or modify the film properties. One of these substances that requires attention is the cellulose nanocrystal $(\mathrm{CN})$ biopolymeric assemblies, not only because of their unique quintessential physical and chemical properties but also because of their inherent renewability, sustainability, and natural abundance [8]. Plasticizers are normally added to the film-forming dispersion, in casting methods, to improve the flexibility of the films and to reduce cohesion within the polymer network by entering between their molecular chains, such as glycerol compound, the most widely used plasticizer [9]. Moreover, new systems can be developed by the incorporation of an antimicrobial substance into a polymer matrix, targeting the increase in food safety through the controlled release of these substances from the carrier film structure to the food surface [10]. Nisin is a natural food preservative heat-stable peptide produced by Lactococcus lactis, which presents activity against several Gram-positive bacteria. A natural nisin variant, designated nisin $Z$, differs from nisin $A$ in a single amino acid and has more solubility at neutral $\mathrm{pH}$, becoming a better compound to be applied in food packaging [11,12].

Nowadays, several composite materials have been developed such as in the work of Sandhu et al. (2020), where edible composite films were developed from pearls millet starch and carrageenan gum blends; in Kochkina and Lukin's (2020) works, environmentally safe multi-purpose composite films were developed based on maize starch low weight chitosan and polyvinyl alcohol, and in Yang et al. (2019) they developed biodegradable and biocompatible films of super-tough poly(L-lactide) PLLA [3,7,9]. However, more film formulations can be developed, and the interactions among substances, mechanical and thermal properties of the films should be investigated for better application. Therefore, this study strives to understand the influence of the interaction among compounds such as maleic anhydride, cellulose nanocrystal, and nisin- $Z$ on the film's thermal and antimicrobial properties to apply as active biodegradable packaging in the food industry.

\section{Materials and Methods}

\subsection{Materials}

The corn starch (CS) containing $72 \%$ of amylopectin was donated by Cargill (Wayzata, MN, USA). The follow compounds were purchased from Sigma-Aldrich (St. Louis, MO, USA): polyvinyl alcohol (PVA) with molecular weight of $85.00-124.00$ and $99 \%$ of hydrolyzed degree; glycerol (GLY); and maleic anhydride (MaAh). The antimicrobial Nisin-Z $(\mathrm{N}-\mathrm{Z})$ was acquired from Handary (Evere, Brussels, Belgium) and cellulose nanocrystal $(\mathrm{CN})$ obtained from Maine University (Orono, ME, USA).

\subsection{Production of the Biodegradable Composite Films}

The biodegradable composite films were prepared according to Oliveira et al.'s methodology (2020) [13]. The films were produced through the mix of two solutions that formed a final polymer dispersion. The first dispersion was obtained through the addition of PVA $3 \mathrm{~g}$ into deionized water, under heating at $82 \pm 3{ }^{\circ} \mathrm{C}$ and agitation for $4 \mathrm{~h}$ at $550 \mathrm{rpm}$; the second dispersion was produced through the addition of $7 \mathrm{~g}$ CS plasticized with $2 \mathrm{~g}$ GLY, and MaAh into $76 \mathrm{~mL}$ of Mili-Q water. Both dispersions were stirred for $15 \mathrm{~min}$ at $550 \mathrm{rpm}$. Then, the compatibilizer compound MaAh, the reinforcement particle $\mathrm{CN}$, and the antimicrobial $\mathrm{N}-\mathrm{Z}$ were added to the film-forming dispersion resulting in 6 treatments such as: T1 $(0 \%, 3.3 \%, 4.5 \%), \mathrm{T} 2(12.6 \%, 3.3 \%, 4,5 \%), \mathrm{T} 3(6.3 \%, 0 \%, 4.5 \%), \mathrm{T} 4$ $(6.3 \%, 6.3 \%, 4.5 \%)$, T5 $(6.3 \%, 3.3 \%, 8.7 \%)$, and T6 (6.3\%, 3.3\% 4.5\%). Each final dispersion was homogenized for $4 \mathrm{~min}$ at $550 \mathrm{rpm}$, poured into glass plates $(18 \times 34) \mathrm{cm}^{2}$ and dried at 
$25 \pm 2{ }^{\circ} \mathrm{C}, 52 \pm 3 \% \mathrm{RH}$, for $48 \mathrm{~h}$. Previous each analysis, the samples were conditioned at $(23 \pm 1){ }^{\circ} \mathrm{C}$ and $(50 \pm 3) \%$ RU.

\subsection{Fourier Transform Infrared Spectroscopy (FTIR)}

FTIR was used to study the chemical interaction between the compounds used to produce the biodegradable active composite film such as MaAh, CN, NZ, GLY, CS, PVA. Spectra were obtained on a Thermo Nicolet 6700 (Thermo Scientific, Waltham, MA, USA) FTIR Spectrophotometer with attenuated total reflectance varying from 4000 to $650 \mathrm{~cm}^{-1}$ wavelengths, 32 scans average, and $2 \mathrm{~cm}^{-1}$ resolution. An empty cell spectrum was used as a background [14].

\subsection{Near-Infrared Hyperspectral Imaging Analysis (NIR-HSI)}

The NIR-HSI analysis was handled according to the methodology of Terra et al. (2020), with adaptations [15]. Only formulations T1, T2, and T6 were analyzed to investigate the dispersion influence of different MA concentration values into the polymer matrix on biodegradable active composite film properties. The formulations chosen had $\mathrm{CN}$ and $\mathrm{N}-\mathrm{Z}$ concentration constant and the MaAh concentration varied from $0 \%$ to $12.6 \%$.

\subsubsection{NIR-HSI Acquisition}

An HSI in the NIR region was acquired for T1, T2, and T6 films using the SisuCHEMA (Specim ${ }^{\circledR}$, Oulu, Finland) chemical imaging system. The images were collected using a line-scan spectroscope, OLE15 lens with a 200-mm field, equipped with a two-dimensional $\mathrm{HgCdTe}$ detector, in wavelength range varying from 928 to $2524 \mathrm{~nm}$, covering 320 space channels and 256 spectral channels, with a spectral resolution of $6.3 \mathrm{~mm}$, achieving 100 frames per second and a scanning speed of $62.5 \mathrm{~mm} / \mathrm{s}$. The hypercubes obtained by this system were 256 images composed of $625 \times 625 \mu \mathrm{m}$ pixels [16].

\subsubsection{Software}

Data analysis was performed through Matlab (Mathworks R2018b, Portola Valley, CA, USA) helps, using MIA_Toolbox version 3.0 Eigenvector (Mason, WA, USA) and PLS_Toolbox version 8.2 Eigenvector (Mason, WA, USA) to process the image, and the MCR-ALS GUI 2.0 program was used to perform the MCR-ALS method [15].

\subsubsection{Image Preprocessing}

Pre-process techniques were used, according to Vidal and Amigo's methodology (2012), to obtain images of $280 \times 140$ pixels and to reduce spatial dimension through data binning application, resulting in $140 \times 80 \times 256$ hypercubes [16]. Each hypercube (F1, F2, F6) was unfolded in a matrix, as shown in Figure 1. Each film and each pure compound, separately, were preprocessed through Image Despike (Filtered Median), Extended Multiplicative Scatter Correction (EMSC), and Savitzky-Golay Smoothing (order 2, window $25 \mathrm{pt}$, incl only, tails polyinterp). Three-dimensional matrices were built and arranged with the preprocessed film matrix vertically concatenated [15].

\subsubsection{Image Resolution by Multivariate Curve Resolution-Alternating Least Squares (MCR-ALS)}

This method was applied to each D-matrix built (DF1, DF2, and DF6.). In this work, the standard spectra of all film components, with components known, were used as the spectra initial estimation. The constraints employed were non-negativity. A maximum of 100 interactions and 0.01 convergence criteria was defined. The relative intensity C-matrix columns were reshaped in a spatial distribution matrix for every pure component and for every film treatment. Nxn pure images of the components were generated in total, called distribution maps, in which $\mathrm{N}$ is the chemical rank of the matrix and $n$ is the number of film images [15]. 


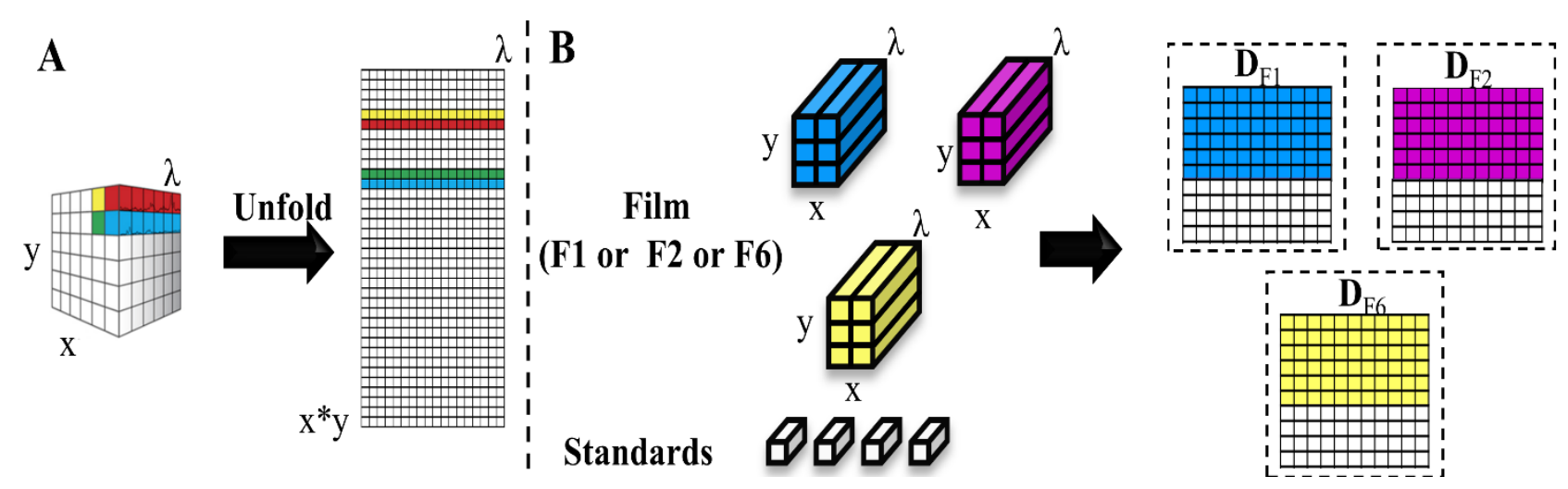

Figure 1. NIR-HSI image as a three-dimensional array (hyperspectral cube) (A) and the unfolding process to give a two-dimensional (XY plane to each $\lambda$ )matrix (A) and steps for the D-matrix arrangement $(\mathbf{B})$.

\subsection{Differential Scanning Calorimetry (DSC)}

The thermal properties of the composite films were evaluated using a differential scanning calorimeter model DSC 60 (Shimadzu Co., Kyoto, Japan) within an atmosphere of pressurized nitrogen flowing at $50 \mathrm{~mL} \cdot \mathrm{min}^{-1}$. Samples of approximately 2 to $3 \mathrm{mg}$ were heated from $30^{\circ} \mathrm{C}$ to $255^{\circ} \mathrm{C}$ at a heating rate of $10^{\circ} \mathrm{C} \cdot \mathrm{min}^{-1}$ (Moraes et al., 2017) [17].

\subsection{Thermogravimetric Analysis (TGA)}

TGA was performed according to Garcia et al. (2014) in a thermogravimetric analyzer, model DTG 60H (Shimadzu Co., Kyoto, Japan) [18]. Samples of approximately 3 to $4 \mathrm{mg}$ were scanned from $25^{\circ} \mathrm{C}$ to $700{ }^{\circ} \mathrm{C}$ at a rate of $10^{\circ} \mathrm{C} \cdot \mathrm{min}^{-1}$ under a $50 \mathrm{~mL} \mathrm{~min}{ }^{-1}$ nitrogen flow rate. Thermogravimetric (TG) and derivative TG (DTG) curves were analyzed to evaluate the thermal stability of the composite films [17].

\subsection{Physical-Mechanical Properties}

Film thickness was measured according to Siripatrawan and Harte (2010) using a digital micrometer (Mitutoyo Absolute, Tester Sangyo Co., Ltd., Tokyo, Japan). Ten measurements were taken at ten random film positions and the mean values were calculated [19]. The films were subjected to mechanical tests to evaluate the tensile stress at break (TSB, \%), elongation at break (EB, mm) and Young's Modulus (YM, MPa), according to ASTM D882, 2009 [20]. Universal Mechanical Testing Machine from INSTRON Corporation (Norwood, MA, USA) was used in the tests, with a load of $1 \mathrm{kN}$, at a traction speed of $5 \mathrm{~mm} \mathrm{~min}^{-1}$. Six specimens of $(17.5 \times 2.5) \mathrm{cm}^{2}$ were tested for each treatment, with a distance of $10.0 \mathrm{~cm}$ from the equipment claws, at $(25 \pm 2){ }^{\circ} \mathrm{C}$ and humidity of $75 \%$.

\subsection{Antimicrobial Activity}

First of all, Salmonella Choleraesuis ATCC 10708, Escherichia coli ATCC11229, Staphylococcus aureus ATCC 6538, and Pseudomonas aeruginosa ATCC 15,442 stocked at $-80 \pm 2{ }^{\circ} \mathrm{C}$ were trigged in Tryptic-Soy-Broth from Merck (Darmstadt, Alemanha) at $36 \pm 1{ }^{\circ} \mathrm{C}$ for $22 \mathrm{~h}$. Then, the bacteria colony was separated by the striation technique in Tryptic-Soy-Agar from (Merck, Darmstadt, Alemanha), hatched at $36 \pm 1{ }^{\circ} \mathrm{C}$ for $22 \mathrm{~h}$, and resuspended in $0.85 \%$ saline solution to achieve the turbidity according to MacFarland Standard 0.5 , assuming the bacteria count was around $10^{8} \mathrm{CFU} \cdot \mathrm{mL}^{-1}$. Film disks of one$\mathrm{cm}$-diameter were applied on solidified Mueller-Hinton agar surface Merck (Darmstadt, Alemanha) that was inoculated with the bacteria early and hatched at $36 \pm 1{ }^{\circ} \mathrm{C}$ for $22 \mathrm{~h}$. The analyses were evaluated in duplicate through measurement of the inhibition halo for each sample disk under different storing periods $(1,7,16$, and 28 days) to analyze the film viability during storage [20]. 


\subsection{Statistical Analysis}

The impact of MaAh, $\mathrm{CN}$, and $\mathrm{N}-\mathrm{Z}$ compounds on the composite film features was evaluated by statical models at the $5 \%$ level of significance level according to analysis of variance (ANOVA). Furthermore, the models were analyzed according to lack-of-fit, the coefficient significance by Student's t-test, and coefficient of determination. Antimicrobial tests were analyzed by Tukey's test, a 5\% significance level.

\section{Results}

\subsection{FTIR and NIR Spectra}

FTIR spectroscopy analysis was done to examine the interactions between the compounds used to produce the composite films, such as MaAh, CN, N-Z, GLY, CS, and PVA. FTIR and NIR spectra and absorption bands of the composite films are shown in Figure 2a,b and Table 1, respectively. Absorption bands of the pure compounds can be observed in Table 2.

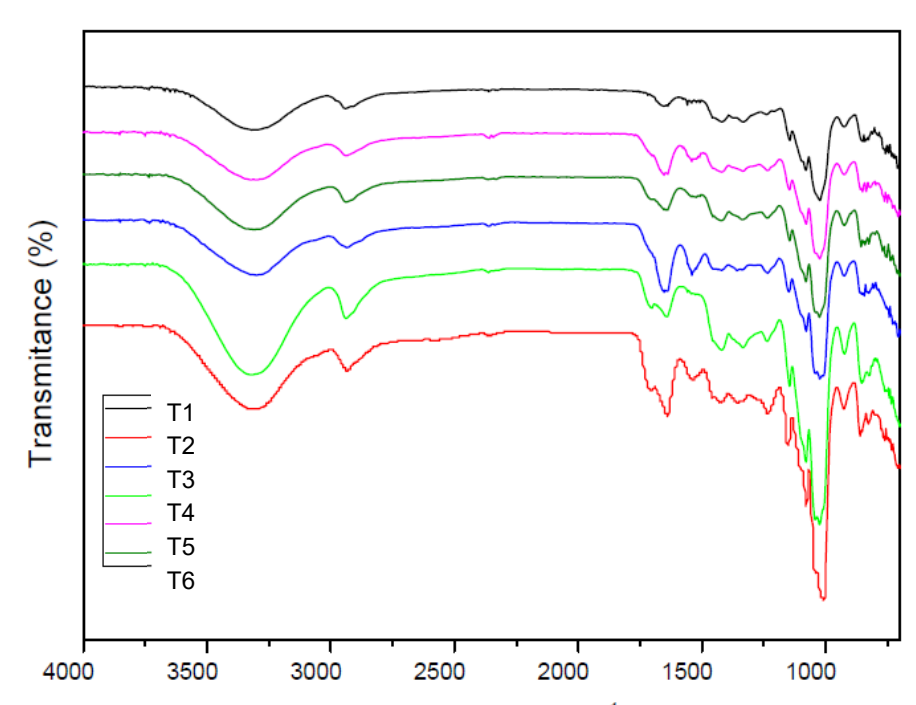

(a) Wavenumber $\left(\mathrm{cm}^{-1}\right)$

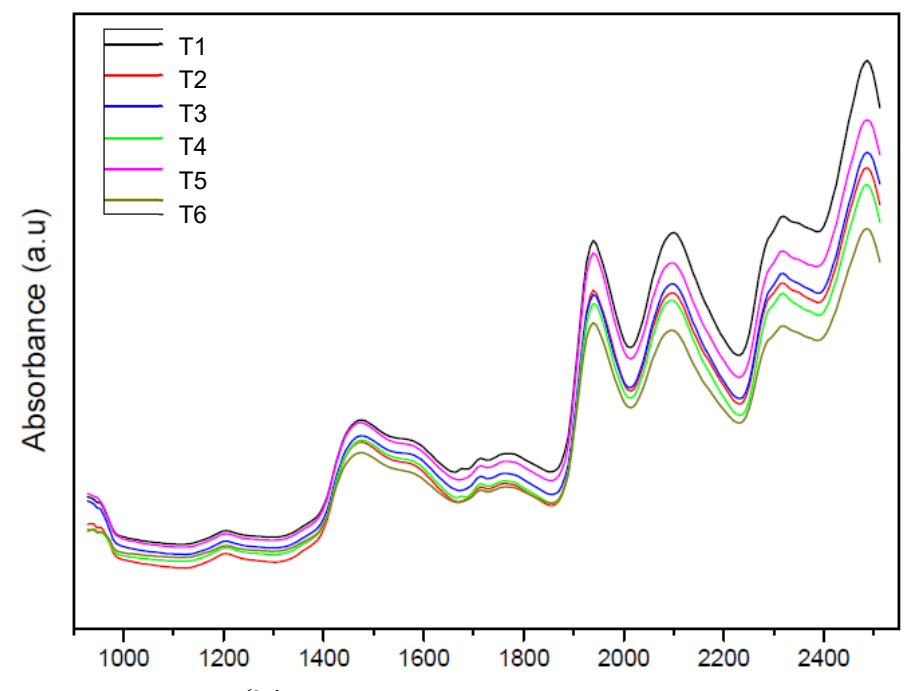

(b) Wavelength $(\mathrm{nm})$

Figure 2. (a) FTIR and (b) NIR spectra of the biodegradable active composite films, which are: T1 $(0.0 \%, 3.3 \%$, $4.5 \%)$; T2 (12.6\%, 3.3\%, 4.5\%); T3 (6.3\%, 0.0\%, 4.5\%); T4 (6.3\%, 6.2\%, 4.5\%); T5 (6.3\%, 3.3\%, 8.7\%), T6 (6.3\%, 3.3\%, 4.5\%) of MaAh, $\mathrm{CN}$ and $\mathrm{N}-\mathrm{Z}$ respectively.

The T1 film did not a present band at $1700 \mathrm{~cm}^{-1}$ related to the $\mathrm{C}=\mathrm{O}$ carboxylic acid from N-Z, indicating that in the absence of MaAh, the carboxyl groups of NIS-Z were completely involved in intermolecular interactions with other film compounds, causing peak displacement to a lower wavelength. On the other hand, from the moment that the MaAh was added, this compound also had interactions between the other compounds, keeping the peak at $1700 \mathrm{~cm}^{-1}$ due to the $\mathrm{C}=\mathrm{O}$ carboxylic acid group from $\mathrm{N}-\mathrm{Z}$, which was observed in Figure 2a and Table 1.

The T2 film showed a peak at $1010 \mathrm{~cm}^{-1}$ relating to the stretching vibration of C-O in $\mathrm{C}-\mathrm{O}-\mathrm{C}$ bonds, mostly present in the glycosidic linkages of CS and CN [21].

The T4 film was the only one that did not present bands at $1540 \mathrm{~cm}^{-1}$ related to the $\mathrm{NH}_{2}$ amide II from $\mathrm{N}-\mathrm{Z}$. Since this is the only treatment added with the highest $\mathrm{CN}$ concentration, it can be inferred that $\mathrm{CN}$, at this concentration, interacted with $\mathrm{NH}_{2}$ amide II of N-Z, causing the peak displacement.

NIR spectra (Figure 2b) illustrate the presence of the characteristic bands for some compounds involved in the blends. The NIR spectra collected for the samples did not show any change that was induced by the different amounts of MaAh, $\mathrm{CN}$, and N-Z incorporated into the CS-PVA plasticized films. CS characteristics were observed at 1215, $1695,1725,1765,1960$, and $2352 \mathrm{~nm}$ corresponding to the $\mathrm{C}-\mathrm{H}$ stretching of the second 
overtone, $\mathrm{C}-\mathrm{H}$ stretching of first overtone $\mathrm{CH}_{3}, \mathrm{C}-\mathrm{H}$ stretching of first overtone $\mathrm{CH}_{2}$, $\mathrm{N}-\mathrm{H}$ asymmetric stretching and amide II of $\mathrm{CONH}_{2}$ and $\mathrm{C}-\mathrm{H}$ deformation of the second overtone of cellulose [16].

Table 1. FTIR spectral absorption bands and functional groups of biodegradable active composite films.

\begin{tabular}{|c|c|c|c|}
\hline Treatment & Bands $\left(\mathrm{cm}^{-1}\right)$ & Functional Groups & Reference \\
\hline \multirow{2}{*}{$\mathrm{T} 1, \mathrm{~T} 2, \mathrm{~T} 3, \mathrm{~T} 4, \mathrm{~T} 5, \mathrm{~T} 6$} & $3320-3300$ & $\begin{array}{l}\checkmark \mathrm{OH} \text { band in bell form present in starch, glycerol, } \mathrm{CNC} \text { and } \\
\text { PVA }\end{array}$ & Barbosa (2008). \\
\hline & $2840-2980$ & $v_{\text {as }} \mathrm{CH}_{3}, v_{\mathrm{s}} \mathrm{CH}_{3}, v_{\mathrm{as}} \mathrm{CH}_{2}$ e $v_{\mathrm{as}} \mathrm{CH}_{2}$ & Barbosa (2008). \\
\hline $\mathrm{T} 2, \mathrm{~T} 3 \mathrm{~T} 4, \mathrm{~T} 5, \mathrm{~T} 6$ & 1700 & $v \mathrm{C}=\mathrm{O}$ carboxylic acid of nisin present in aminoacids & Barbosa (2008). \\
\hline $\mathrm{T} 1, \mathrm{~T} 2, \mathrm{~T} 3, \mathrm{~T} 4, \mathrm{~T} 5, \mathrm{~T} 6$ & 1640 & $v \mathrm{C}=\mathrm{C}$. & Barbosa (2008). \\
\hline $\mathrm{T} 1, \mathrm{~T} 2, \mathrm{~T} 3, \mathrm{~T} 5, \mathrm{~T} 6$ & 1540 & $\delta \mathrm{NH}_{2}$ amide II band present in nisin $\mathrm{Z}$. & Barbosa (2008). \\
\hline \multirow[t]{2}{*}{$\mathrm{T} 1, \mathrm{~T} 2, \mathrm{~T} 3, \mathrm{~T} 4, \mathrm{~T} 5, \mathrm{~T} 6$} & $1440-1430$ & $\delta_{\mathrm{s}} \mathrm{CH}_{2}$ & $\begin{array}{l}\text { Barbosa (2008) and } \\
\text { Pereira et al. (2015). }\end{array}$ \\
\hline & 1350 & $\delta \mathrm{CH}$ & Barbosa (2008). \\
\hline $\mathrm{T} 2, \mathrm{~T} 3, \mathrm{~T} 4, \mathrm{~T} 5, \mathrm{~T} 6$ & 1230 & $\checkmark \mathrm{C}-\mathrm{O}$ present in anidride ciclic & Barbosa (2008). \\
\hline $\mathrm{T} 2, \mathrm{~T} 3, \mathrm{~T} 4, \mathrm{~T} 5, \mathrm{~T} 6$ & 1150 & $\begin{array}{l}\vee \mathrm{C}-\mathrm{O}-\mathrm{C} \text { from maleic anhydride ring; } \vee \mathrm{C}-\mathrm{O} \text { tertiary } \\
\text { alcohol present in glycerol, starch and } \mathrm{CNC} \text {. }\end{array}$ & Barbosa (2008). \\
\hline $\mathrm{T} 1$ & 1140 & $\checkmark \mathrm{C}-\mathrm{O}$ tertiary alcohol present in starch, glycerol and CNC. & Barbosa (2008). \\
\hline $\mathrm{T} 1, \mathrm{~T} 3, \mathrm{~T} 5$ & 1080 & $\begin{array}{l}\vee \mathrm{C}-\mathrm{O} \text { primary alcohol present in } \mathrm{CH}_{2} \mathrm{OH} \text { ramification and } \\
\text { directly bonding into glucose starch, } \mathrm{CNC} \text { and glycerol. }\end{array}$ & Barbosa (2008). \\
\hline $\mathrm{T} 2, \mathrm{~T} 4, \mathrm{~T} 6$ & 1070 & $\begin{array}{l}\vee \mathrm{C}-\mathrm{O}-\mathrm{C} \text { present in maleic anhydride ring; } v \mathrm{C}-\mathrm{O} \text { glycerol } \\
\text { tertiary alcohol; } v \mathrm{C}-\mathrm{O} \text { primary alcohol present in } \mathrm{CH}_{2} \mathrm{OH} \\
\text { ramification and directly bonding into starch ring and } \mathrm{CNC} \text {. }\end{array}$ & Barbosa (2008). \\
\hline $\mathrm{T} 3, \mathrm{~T} 4, \mathrm{~T} 5, \mathrm{~T} 6$ & $1040-1022$. & $\begin{array}{l}\vee \mathrm{C}-\mathrm{O} \text { primary alcohol present in } \mathrm{CH}_{2} \mathrm{OH} \text { ramification and } \\
\text { directly bonding into glucose starch, } \mathrm{CNC} \text { and glycerol. }\end{array}$ & Barbosa (2008). \\
\hline $\mathrm{T} 2$ & 1010 & $\begin{array}{l}\text { stretching vibration of } \mathrm{C}-\mathrm{O} \text { in } \mathrm{C}-\mathrm{O}-\mathrm{C} \text { bonds, mostly present } \\
\text { in the glycosidic linkages }\end{array}$ & Olivato et al. (2012) \\
\hline $\mathrm{T} 1, \mathrm{~T} 3, \mathrm{~T} 4, \mathrm{~T} 5, \mathrm{~T} 6$ & 860 & $\gamma \mathrm{NH}_{2}$ angular deformation of plan of nisin $\mathrm{Z}$ amine & Barbosa (2008). \\
\hline
\end{tabular}

Table 2. FTIR spectral absorption bands of MA, starch, and PVA.

\begin{tabular}{|c|c|c|c|}
\hline Compound & Bands $\left(\mathrm{cm}^{-1}\right)$ & Functional Groups & Reference \\
\hline \multirow{6}{*}{ MA } & 3080 & $v_{\mathrm{as}}=\mathrm{CH}$ ring presence & Barbosa (2008). \\
\hline & 2975 & $v_{\mathrm{s}}=\mathrm{CH}$ ring presence & Barbosa (2008). \\
\hline & 1826 & $v_{\text {as }} \mathrm{C}=\mathrm{O}$ ciclic anhydride. & Barbosa (2008). \\
\hline & 1623 & $\vee C=C$ ring presence & Barbosa (2008). \\
\hline & 1250 & v C-O ciclic anhydride & Murillo and López (2015). \\
\hline & 880 & $\checkmark \mathrm{C}-\mathrm{O}-\mathrm{C}$ ring presence & Barbosa (2008). \\
\hline \multirow{3}{*}{ Starch } & $3066-3658(3340)$ & $\begin{array}{l}\vee \mathrm{OH} \text { bell-shaped band present in the } \mathrm{CH}_{2} \mathrm{OH} \text { branching and } \\
\text { attached directly into the amido ring. }\end{array}$ & Barbosa (2008). \\
\hline & 2930 & $v_{\text {as }} \mathrm{CH}_{2}$. & Barbosa (2008). \\
\hline & 1099 & $\begin{array}{l}\vee \mathrm{C}-\mathrm{O} \text { secondary alcohol present in ring and } \vee \mathrm{C}-\mathrm{O}-\mathrm{C}-\mathrm{O}-\mathrm{C} \\
\text { glycosidic bond (acetal). }\end{array}$ & $\begin{array}{l}\text { Barbosa (2008) and } \\
\text { Teixeira et al. (2017). }\end{array}$ \\
\hline \multirow{4}{*}{ PVA } & $3580-3700$ & v OH bell-shaped band & Barbosa (2008). \\
\hline & $2860-2975$ & $v_{\mathrm{as}}$ and $v_{\mathrm{s}} \mathrm{CH}_{3}$ terminal, $v_{\text {as }}$ and $v_{\mathrm{s}} \mathrm{CH}_{2}$. & Barbosa (2008). \\
\hline & 1470 & $\delta_{\mathrm{s}} \mathrm{CH}_{2}$ & $\begin{array}{l}\text { Barbosa (2008), Pereira } \\
\text { et al. (2015). }\end{array}$ \\
\hline & 1380 & $\delta_{\mathrm{s}} \mathrm{CH}_{3}$ & Barbosa (2008). \\
\hline
\end{tabular}


Table 2. Cont.

\begin{tabular}{|c|c|c|c|}
\hline Compound & Bands $\left(\mathrm{cm}^{-1}\right)$ & Functional Groups & Reference \\
\hline & 1080 & v C-O secondary alcohol & $\begin{array}{l}\text { Barbosa (2008), Xu et al. } \\
\text { (2005). }\end{array}$ \\
\hline & 735 & $\rho \mathrm{CH}_{2}$ deformation & Barbosa (2008). \\
\hline
\end{tabular}

\subsection{NIR-HSI-MCR-ALS Analysis}

One spectrum of every pure component was obtained for NIR-HSI, and one pixel of each of these images is shown in Figure 3. The recovered NIR spectra by MCR-ALS for CS, PVA, GLY, CN, N-Z, and MaAh are also presented in Figure 3, Figure A1 (Appendix A). Both models, NIR-HSI and MCR-ALS, explained more than $99 \%$ of the D matrix with a lack-of-fit higher than 1.0\% for MCR-ALS, corroborating with Terra et al. (2020) [15]. The distribution maps of film components were built, as shown in Figure 4.
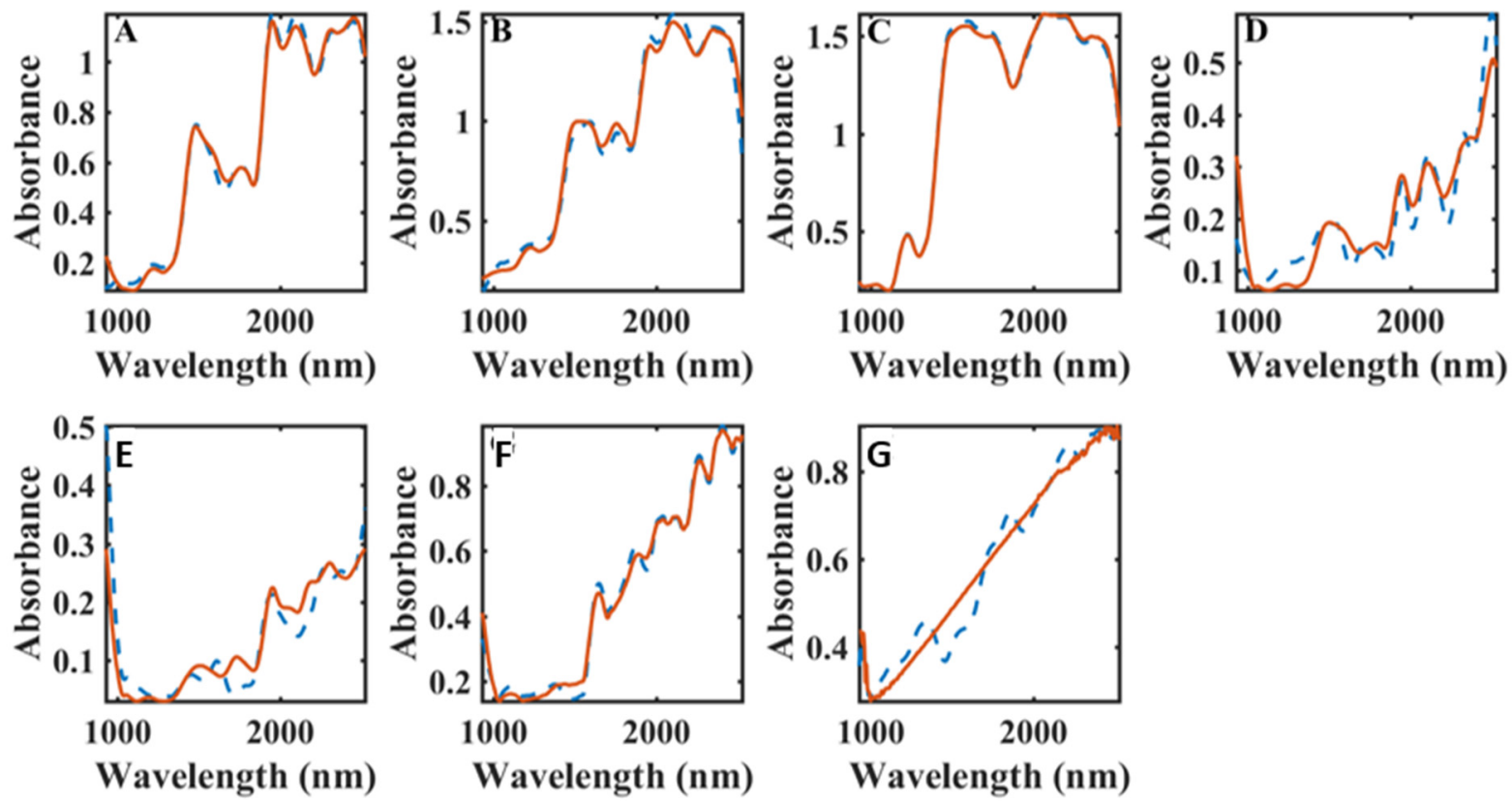

Figure 3. MCR-ALS-NIR spectra profile: (blue dashed lines) compared with standard spectra (red continuous line) and their correlation coefficient $\left(R^{2}\right)$ values for $(A)$ starch $\left(R^{2}=0.995\right),(B) P V A\left(R^{2}=0.989\right),(C)$ GLY $\left(R^{2}=0.999\right),(D) C N\left(R^{2}=0.883\right)$, (E) N-Z $\left(R^{2}=0.816\right)$, (F) MaAh $\left(R^{2}=0.994\right)$, and $(G)$ Teflon $\left(R^{2}=0.958\right)$, for $T 2(12.6 \%, 3.3 \%, 4.5 \%)$ film formulations. The spectrum for the T1 and T6 formulations can be observed in the topic (Figure A1, Appendix A).

The compounds are heterogeneously dispersed along the composite films, as shown in the maps (Figure 4). Overall, it was observed that the CS compound was concentrated in the middle of the films, whereas PVA was found mainly on the left extremity, as well as $\mathrm{CN}$ and MaAh compounds when MaAh was added. This behavior indicates a high affinity between $\mathrm{CN}$, MaAh, and PVA rather than with CS. No patterns could be observed for $\mathrm{N}-\mathrm{Z}$ and GLY compounds, and due to the plasticizer features, they spread better than other compounds.

\subsection{Differential Scanning Calorimetry (DSC) and Thermogravimetry (TGA)}

DSC thermograms of normal and amplified size can be observed in Figure 5a,b. One endothermic event happened between $189.0^{\circ} \mathrm{C}$ and $197.0^{\circ} \mathrm{C}$ and the enthalpy variations were determined for all films, as shown in Table 3. 
T1
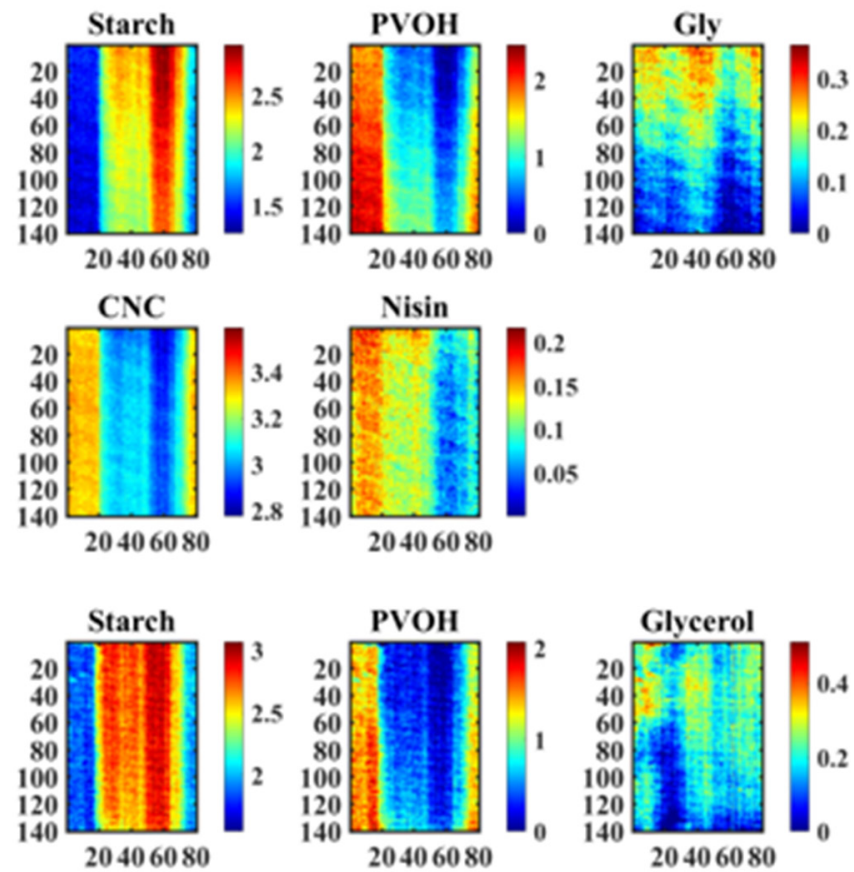

T6
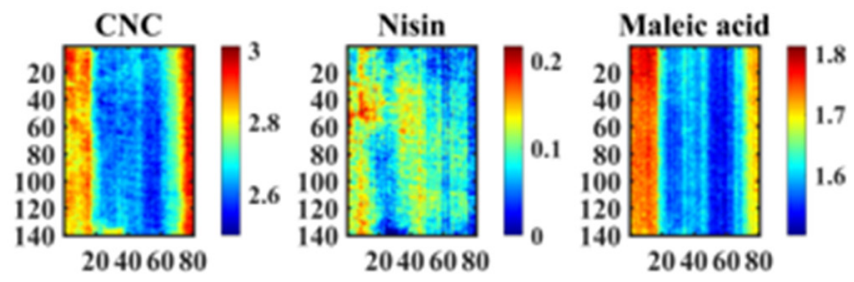

T2
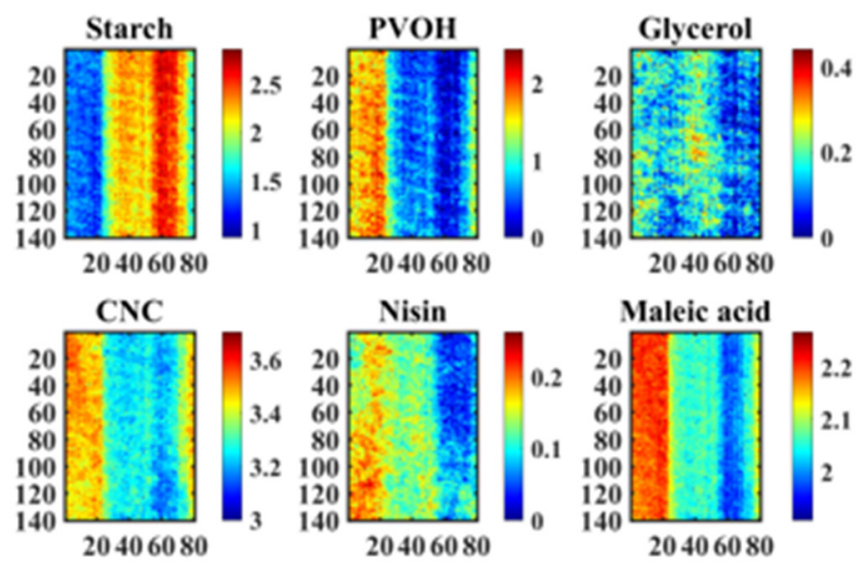

Figure 4. Component distribution maps for T1, T6 and T2 films. T1 (0.0\%, 3.3\%, 4.5\%); T2 (12.6\%, $3.3 \%, 4.5 \%)$ and $\mathrm{T} 6(6.3 \%, 3.3 \%, 4.5 \%)$ of MaAh, $\mathrm{CN}$ and N-Z, respectively.

The highest heat of fusion was observed $\left(\Delta \mathrm{H}_{\mathrm{f}} 155.1 \mathrm{~J} \mathrm{~g}^{-1}\right)$ for the $\mathrm{T} 2$, incorporated with the highest $\mathrm{MaAh}$ concentration $(12.6 \%)$, which indicated superior molecular interaction between, mainly, the MaAh, CN, N-Z, and PVA matrix caused by esterification reactions (crosslinking) and hydrogen bonding. Gupta, Fumar, and Sharma (2010) observed low enthalpy variations for composite films produced with low-density polyethylene (LDPE) and $15 \% \mathrm{CS}$ grafted, around $\Delta \mathrm{H}_{\mathrm{f}} 27.46 \mathrm{~J} \mathrm{~g}^{-1}$ [22]. On the other hand, the compatibilizer enhancement probably resulted in the opening of the polymer chain, which caused a slight reduction of the temperature melting (around $191^{\circ} \mathrm{C}$ ).

Similarly, the T4 treatment, incorporating the highest $\mathrm{CN}$ concentration $(6.2 \%)$, pulled away the polymeric chains, reducing the melting temperature (around $190^{\circ} \mathrm{C}$ ), which was lower than that of $\mathrm{T} 6$ treatment $\left(197.7^{\circ} \mathrm{C}\right)$, with the same MaAh and $\mathrm{N}-\mathrm{Z}$ concentrations 
(6.3\% and $4.5 \%$, respectively) and lower $\mathrm{CN}$ concentration (3.3\%). On the other hand, the $\mathrm{T} 6\left(\Delta \mathrm{H}_{\mathrm{f}} 140.4\right)$ exhibited higher heat of fusion than the $\mathrm{T} 4\left(\Delta \mathrm{H}_{\mathrm{f}} 128.5\right)$ due to the addition of more $\mathrm{CN}$ amounts into $\mathrm{T} 6$ blends. This effect can be explained by the fact that $\mathrm{CN}$ addition into the polymeric chain needs an additional temperature to break intermolecular forces existent in the crystalline portion, consequently increasing the heat of fusion [23-25].
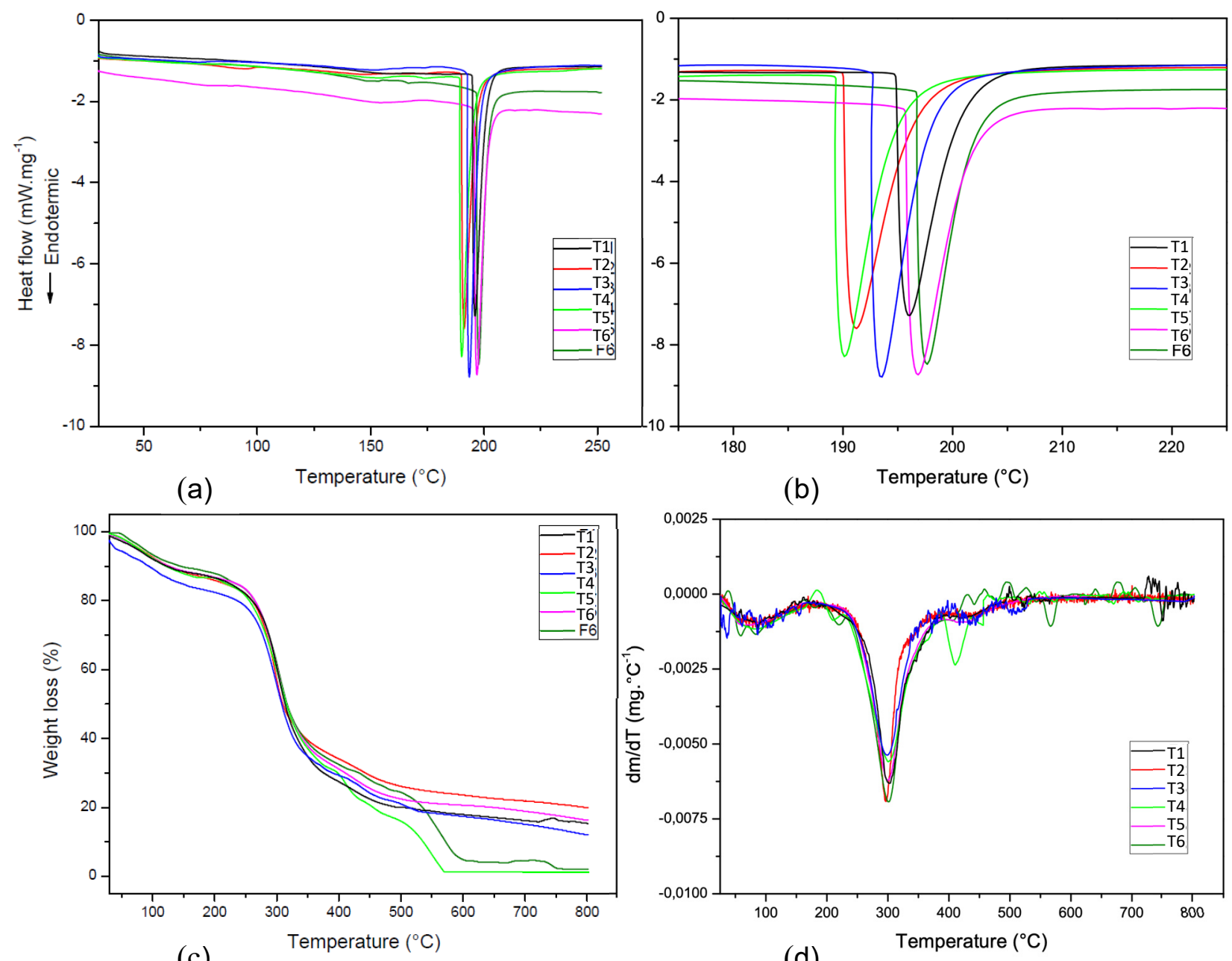

Figure 5. DSC curve (a), DSC zoom ratio (b), TGA curve (c) and DTG curve (d) of the biodegradable composite active films, which are T1 (0.0\%, 3.3\%, 4.5\%); T2 (12.6\%, 3.3\%, 4.5\%); T3 (6.3\%, 0.0\%, 4.5\%); T4 (6.3\%, 6.2\%, 4.5\%); T5 (6.3\%, 3.3\%, 8.7\%), $\mathrm{T} 6(6.3 \%, 3.3 \%, 4.5 \%)$ of MaAh, $\mathrm{CN}$ and $\mathrm{N}-\mathrm{Z}$ respectively.

The lowest heat of fusion was observed $\left(\Delta \mathrm{H}_{\mathrm{f}} 130.9 \mathrm{~J} \mathrm{~g}^{-1}\right)$ for the $\mathrm{T} 1$, without MaAh incorporation, and this effect occurred due to the lack of existence of the crosslinking formation.

To summarize, the increase of MaAh concentrations increased the heat of fusion due to the increment of the crosslink among the compounds, however, this effect provoked a distance in the polymeric chains, reducing the melting temperature. Similarly, the CN addition into the polymeric matrices increased the heat of fusion due to the enhancement of the crystalline portion, however, if the $\mathrm{CN}$ concentration was enough to pull out the polymeric chain, such as at $6.3 \%$, the melting temperature would reduce.

The N-Z effect can be observed through a comparative analysis between the $\mathrm{T} 5$ and the $\mathrm{T} 6$ treatment. The increment in the $\mathrm{N}-\mathrm{Z}$ amount from $8.7 \%$ in $\mathrm{T} 5$ to $4.5 \%$ in $\mathrm{T} 6$ increased the intermolecular interaction, increasing the heat of fusion from 143.2 to $128.5 \mathrm{~J} \mathrm{~g}^{-1}$, but the polymeric chain distance was maintained, where both treatments exhibited similar melting temperatures, around $197^{\circ} \mathrm{C}$. 
Table 3. Melting temperature in the beggining $\left(\mathrm{T}_{\mathrm{mb}}\right)$, at the peak $\left(\mathrm{T}_{\mathrm{mp}}\right)$ and in the end $\left(\mathrm{T}_{\mathrm{me}}\right)$ of the thermal event, heat of fusion $\left(\Delta \mathrm{H}_{\mathrm{f}}\right)$, initial temperature $\left(\mathrm{T}_{\mathrm{i}}\right)$, final temperatura $\left(\mathrm{T}_{\mathrm{f}}\right)$, temperature of maximum thermal degradation $\left(\mathrm{T}_{\mathrm{p}}\right)$ and weight loss $(\Delta \mathrm{w})$ for each biodegradable active composite film.

\begin{tabular}{ccccc}
\hline Treatment & $\mathbf{T}_{\mathbf{m b}}\left({ }^{\circ} \mathbf{C}\right)$ & $\mathbf{T}_{\mathbf{m p}}\left({ }^{\circ} \mathbf{C}\right)$ & $\mathbf{T}_{\mathbf{m e}}\left({ }^{\circ} \mathbf{C}\right)$ & $\boldsymbol{\Delta H}_{\mathbf{f}}\left(\mathbf{J ~} \mathbf{g}^{-\mathbf{1}}\right)$ \\
\hline $\mathrm{T} 1$ & 194.5 & 195.9 & 205.5 & 130.9 \\
\hline $\mathrm{T} 2$ & 189.6 & 191.2 & 202.7 & 155.1 \\
\hline $\mathrm{T} 3$ & 192.4 & 193.4 & 202.9 & 142.6 \\
\hline $\mathrm{T} 4$ & 189.1 & 190.1 & 200.0 & 140.4 \\
\hline $\mathrm{T} 5$ & 195.4 & 196.9 & 206.3 & 143.2 \\
\hline $\mathrm{T} 6$ & 196.5 & 197.7 & 207.1 & 128.5 \\
\hline
\end{tabular}

\begin{tabular}{|c|c|c|c|c|c|c|c|c|c|}
\hline \multirow[t]{2}{*}{ Films } & \multicolumn{3}{|c|}{ Event 1} & \multicolumn{3}{|c|}{ Event 2} & \multicolumn{3}{|c|}{ Event 3 * } \\
\hline & $\mathrm{T}_{\mathrm{i}}-\mathrm{T}_{\mathrm{f}}\left({ }^{\circ} \mathrm{C}\right)$ & $\mathrm{T}_{\mathrm{p}}\left({ }^{\circ} \mathrm{C}\right)$ & $\Delta \mathrm{w}(\%)$ & $\mathrm{T}_{\mathrm{i}}-\mathrm{T}_{\mathrm{f}}\left({ }^{\circ} \mathrm{C}\right)$ & $\mathrm{T}_{\mathrm{p}}\left({ }^{\circ} \mathrm{C}\right)$ & $\Delta \mathrm{w}(\%)$ & $\mathrm{T}_{\mathrm{i}}-\mathrm{T}_{\mathrm{f}}\left({ }^{\circ} \mathrm{C}\right)$ & $\mathrm{T}_{\mathrm{p}}\left({ }^{\circ} \mathrm{C}\right)$ & $\Delta \mathrm{w}(\%)$ \\
\hline $\mathrm{T} 1$ & 30-166 & 78 & 12 & $182-390$ & 303 & 72 & $382-534$ & 429 & 69 \\
\hline $\mathrm{T} 2$ & $30-166$ & 78 & 12 & $182-390$ & 297 & 65 & $382-534$ & 429 & 69 \\
\hline $\mathrm{T} 3$ & 30-166 & 78 & 16 & $182-390$ & 299 & 71 & $382-534$ & 429 & 71 \\
\hline $\mathrm{T} 4$ & $30-166$ & 78 & 13 & $182-390$ & 300 & 70 & - & - & - \\
\hline $\mathrm{T} 5$ & 30-166 & 78 & 12 & $182-390$ & 300 & 68 & $382-534$ & 429 & 73 \\
\hline T6 & $30-166$ & 78 & 16 & $182-390$ & 299 & 71 & - & - & - \\
\hline
\end{tabular}

*-The third thermal event was not observed for F4 and F6 treatments.

Weight loss and heat flow of the biodegradable composite active films can be observed at TGA and DTG curves in Figure 5c,d. First of all, three heat events happened regardless of the MaAh, CN, and N-Z amount incorporated into the CS-PVA plasticizer matrix. For TGA data, the first thermal event occurred between $30^{\circ} \mathrm{C}$ and $166^{\circ} \mathrm{C}$, which was related to weight loss caused by water evaporation. The water was used as a solvent to dissolve the polymers and it was retained in the matrix during the film production, since water has a high affinity with CS-PVA, CN, and MaAh compounds [23]. In Pola's (2017) study, the first thermal event for CS-PVA film incorporated with cellulose nanocrystal occurred between $65^{\circ} \mathrm{C}$ and $85^{\circ} \mathrm{C}$, and for the films not incorporated with $\mathrm{CN}$, the temperature rate was lower. Weight loss related to water desorption and evaporation was enhanced for the T3 film, where the cellulose nanocrystal was not added, and the F6 film [26]. According to Oliveira et al. (2020), the CN incorporation into the CS-PVA matrix was responsible for filling the polymer interchain, reducing the free space available for water incorporation [13].

The second thermal event began at $180^{\circ} \mathrm{C}$ and it was related to a dehydration reaction of the main chain of the polymer, followed by the formation of volatile compounds, scission, and depolymerization due to MaAh, CN, GLY, PVA, and CS decomposition [23]. At the same temperature range, there were glycosidic bond breaks between amylose and amylopectin, as was also observed by Moraes et al. (2017) and Garcia $(2014)[17,18]$. Glycerol volatilization was observed by Rahman et al. (2010) at $290{ }^{\circ} \mathrm{C}$ [25].

The third thermal event occurred around $400{ }^{\circ} \mathrm{C}$ due to the degradation of the byproduct generated from carbonaceous material during the second thermal event [23]. Although the thermal events occurred at the same temperature range regardless of the difference among films, variation in the weight loss of the active biodegradable composite films can be observed in Table 4. Furthermore, for T4 and T6 films, the third event was not observed, since all the compounds were degraded in the second event.

\subsection{Physical-Mechanical Properties of the Composite Films}

As expected, the higher MaAh concentration added into the polymeric matrix increased the YM and the TSB, since more transesterification and hydrogen reactions happened. This cross linking increases the web connection, reducing the mobility of the 
polymeric chain, which improves the rigidity and, consequently, the strength needed to break them. Similarly, the gradual increase of $\mathrm{CN}$ and $\mathrm{N}-\mathrm{Z}$ concentrations gradually increased the YM values due to the addition of the crystallinity portion and the increase of hydrogen interaction, corroborating the DSC results. On the other hand, the EB attribute reduced with MaAh, N-Z, and CN addition, as also expected since the increase of the rigidity of the films generally causes the reduction of their elongation.

Table 4. Physical-mechanical properties of the biodegradable composite active films.

\begin{tabular}{ccccc}
\hline Treatment & Thickiness $(\mathbf{m m})$ & TSB $(\mathbf{M P a})$ & EB $(\mathbf{m m})$ & YM \\
\hline T1 & 0.159 & 6.16 & 72.09 & 129.95 \\
\hline T2 & 0.127 & 7.02 & 69.77 & 206.20 \\
\hline T3 & 0.196 & 4.24 & 99.00 & 57.96 \\
\hline T4 & 0.187 & 4.78 & 18.35 & 132.91 \\
\hline T5 & 0.183 & 4.73 & 64.81 & 76.89 \\
\hline T6 & 0.177 & 2.82 & 72.94 & 27.38
\end{tabular}

TSB = Tensile strength at break; EB = Elongation at break; YM = Young modulus. T1 (0.0\%, 3.3\%, 4.5\%); T2 (12.6\%, $3.3 \%, 4.5 \%)$; T3 $(6.3 \%, 0.0 \%, 4.5 \%)$; T4 $(6.3 \%, 6.2 \%, 4.5 \%)$; T5 $(6.3 \%, 3.3 \%, 8.7 \%)$, T6 $(6.3 \%, 3.3 \%, 4.5 \%)$ are the compounds added of $\mathrm{MaAh}, \mathrm{CN}$ and $\mathrm{N}-\mathrm{Z}$, respectively, into the polymeric matrices.

\subsection{Antimicrobial Effect of the Composite Films over Time}

The $\mathrm{N}-\mathrm{Z}$ concentration (around 130 and $260 \mathrm{mM}$ ) added into the polymeric matrices to produce the biodegradable active films was higher than the minimum inhibitory concentration described by Kuwano et al. (2005) against S. aureus and E. coli, which was 1 and $>75 \mu \mathrm{M}$, respectively, and antimicrobial activity was observed against the P. aeruginosa, S. aureus, S. Choleraesuis, and E. coli [27]. The antimicrobial effect against $P$. aeruginosa, S. aureus, S. Choleraesuis, and E. coli was affected by the MaAh, CN, and N-Z addition into biodegradable composite films under different storage times $(1,7,16$, and 28 days). $S$. Choleraesuis, and E. coli were inhibited only due to the contact between the film and the microorganisms, regardless of the composition of the films and the storage time; whereas for P. aeruginosa and S. aureus, besides contact inhibition, the diffusion of the compounds from the film caused an inhibition zone, as described in Figure 6 and Table 5.

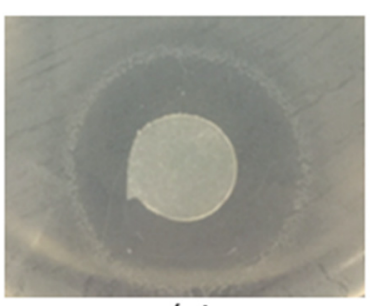

(a)

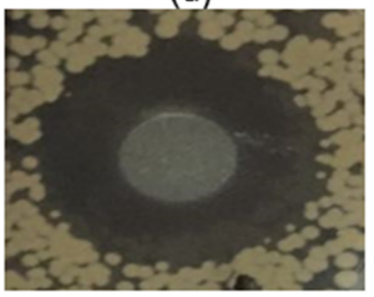

(c)

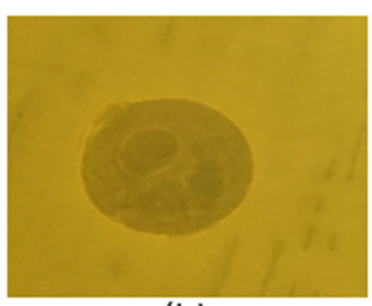

(b)

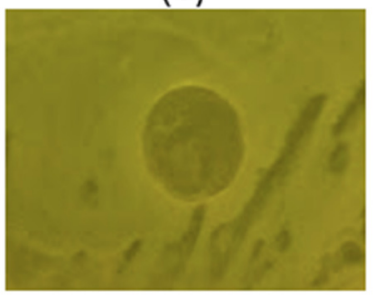

(d)

Figure 6. Antimicrobial activity of the biodegradable active composite films against (a) P. aeruginosa, (b) S. Choleraesuis, (c) S. aureus, and (d) E. coli. 
Table 5. Halo inhibition zone measured in $\mathrm{cm}$ to estimate the antimicrobial activity of starch-PVA plasticizer blends incorporated within MA, CNC and NIS-Z against S. aureus and P. aeruginosa.

\begin{tabular}{|c|c|c|c|c|}
\hline \multirow[b]{3}{*}{ Treatment } & \multicolumn{4}{|c|}{ Staphylococcus Aureus } \\
\hline & \multicolumn{4}{|c|}{ Storage Days } \\
\hline & 1 & 7 & 14 & 21 \\
\hline $\mathrm{T} 1$ & $1.85 \pm 0.01 \mathrm{a}, \mathrm{x}$ & $1.73 \pm 0.16_{a, x}$ & $1.8 \pm 0.02 \mathrm{a}, \mathrm{x}$ & $1.96 \pm 0.03 \mathrm{a}, \mathrm{x}$ \\
\hline $\mathrm{T} 2$ & $1.83 \pm 0.11_{\mathrm{a}, \mathrm{x}}$ & $1.93 \pm 0.01 \mathrm{a}, \mathrm{x}$ & $1.97 \pm 0.01 \mathrm{a}, \mathrm{x}$ & $2.13 \pm 0.07 \mathrm{a}, \mathrm{x}$ \\
\hline T3 & $1.86 \pm 0.03 \mathrm{a}, \mathrm{x}$ & $1.80 \pm 0.01_{\mathrm{a}, \mathrm{x}}$ & $1.77 \pm 0.21_{\mathrm{a}, \mathrm{x}}$ & $2.02 \pm 0.08 \mathrm{a}, \mathrm{x}$ \\
\hline $\mathrm{T} 4$ & $1.77 \pm 0.27 \mathrm{a}, \mathrm{x}$ & $1.95 \pm 0.02 \mathrm{a}, \mathrm{x}$ & $1.54 \pm 0.03 \mathrm{a}, \mathrm{x}$ & $1.59 \pm 0.07_{b, x}$ \\
\hline $\mathrm{T} 5$ & $1.86 \pm 0.05 a, x$ & $1.83 \pm 0.04 \mathrm{a}, \mathrm{x}$ & $1.74 \pm 0.23 \mathrm{a}, \mathrm{x}$ & $1.62 \pm 0.08_{b, x}$ \\
\hline \multirow[t]{3}{*}{$\mathrm{T} 6$} & $1.94 \pm 0.01_{\mathrm{a}, \mathrm{x}}$ & $1.94 \pm 0.05 \mathrm{a}, \mathrm{x}$ & $1.79 \pm 0.01 \mathrm{a}, \mathrm{y}$ & $1.80 \pm 0.04 \mathrm{a}, \mathrm{y}$ \\
\hline & \multicolumn{4}{|c|}{ Pseudomonas Aeruginosa } \\
\hline & \multicolumn{4}{|c|}{ Storage Days } \\
\hline Treatment & 1 & 7 & 14 & 21 \\
\hline $\mathrm{T} 1$ & $2.23 \pm 0.18 \mathrm{a}, \mathrm{x}$ & $2.02 \pm 0.54 \mathrm{a}, \mathrm{x}$ & $2.30 \pm 0.23 \mathrm{a}, \mathrm{x}$ & $2.33 \pm 0.01 \mathrm{a}, \mathrm{x}$ \\
\hline $\mathrm{T} 2$ & $2.27 \pm 0.18_{\mathrm{a}, \mathrm{x}}$ & $2.44 \pm 0.01_{\mathrm{a}, \mathrm{x}}$ & $2.20 \pm 0.01 \mathrm{a}, \mathrm{x}$ & $2.12 \pm 0.17_{\mathrm{ab}, \mathrm{x}}$ \\
\hline T3 & $2.26 \pm 0.22 a, x$ & $2.45 \pm 0.07 \mathrm{a}, \mathrm{x}$ & $2.00 \pm 0.05 a, x$ & $2.02 \pm 0.14 \mathrm{ab,x}$ \\
\hline $\mathrm{T} 4$ & $2.12 \pm 0.28 \mathrm{a}, \mathrm{x}$ & $2.07 \pm 0.41_{a, x}$ & $2.14 \pm 0.14 a, x$ & $2.36 \pm 0.17 a, x$ \\
\hline $\mathrm{T} 5$ & $2.18 \pm 0.45 \mathrm{a}, \mathrm{x}$ & $2.13 \pm 0.21_{\mathrm{a}, \mathrm{x}}$ & $2.16 \pm 0.34 \mathrm{a}, \mathrm{x}$ & $1.85 \pm 0.01_{b, x}$ \\
\hline T6 & $2.05 \pm 0.24_{\mathrm{a}, \mathrm{x}}$ & $2.09 \pm 0.22 a, x$ & $1.95 \pm 0.13 \mathrm{a}, \mathrm{x}$ & $2.11 \pm 0.12 \mathrm{ab}, \mathrm{x}$ \\
\hline
\end{tabular}

The same letters ( $\mathrm{a}$ or $\mathrm{b}$ ) in the same column did not differ statistically (non-significant for $p>0.05$ ). The same letters ( $\mathrm{x}$ or $\mathrm{y}$ ) in the same line did not differ statistically (non-significant for $p>0.05$ ).

The difference in the antimicrobial activity among treatments and storage time was slightly for S. aureus and P. aeruginosa. T4 and T5 had lower halo inhibition zone, which refers to a lower antimicrobial activity against $S$. aureus, after 21 days of storage.

\section{Discussion}

In this work, for all films, the peak at $1826 \mathrm{~cm}^{-1}$ that corresponds to $\mathrm{C}=\mathrm{O}$ of the carboxyl groups of the cyclic anhydride was absent in the FTIR spectral of the biodegradable active composite films, but it was present in the spectrum of the MaAh pure compound. This behavior indicated that the maleic anhydride ring was opened and it was converted into maleic acid as suggested by Olivato et al. (2012) [21]. Besides that, the absence of the MaAh carboxyl groups can indicate the transesterification between MA and the other compounds, such as PVA, GLY, CN, and N-Z.

$\mathrm{CN}$ intermediary amounts favored the polymer chain compatibilization improving the film thermal stability. This behavior corroborates with Canevarolo Jr. (2010), who observed an interaction between nanocellulose and the polymer matrix, which causes polymer chain packaging and enhancement of the crystalline domains [28]. Therefore, more temperature was necessary to break intermolecular forces existent in the crystalline portion to destroy the packaging structure and, hence, to melt the material. Similarly, the esterification reaction between MA and the film components enhanced the crosslinking of the polymeric chain, and consequently, enhanced the heat of fusion. Besides these reactions, hydrogen bonding would occur among carbonyl groups from MaAh, PVA, CN, and CS [29].

The incorporation of MaAh, $\mathrm{CN}$, and N-Z into the polymer matrix was responsible for improving the antimicrobial activity against $S$. aureus and $P$. aeruginosa. In accordance with Olivato et al. (2012), possibly the $\mathrm{C}=\mathrm{O}$ ring of the MaAh broke; as a consequence, the MaAh ring opened and the compound changed to a maleic acid structure, corroborating the FTIR results [21]. Razavi et al.'s work (2020) demonstrated that maleic acid was able to inhibit 
the glutamate decarboxylase from L. monocytogenes [30]. Furthermore, three constitutive lysine residues in nisin $\mathrm{Z}$ may be sufficient to initiate the process of cytoplasmic membrane permeabilization responsible for the compound's antimicrobial activity.

According to Azahari, Othman, and Ismail (2011), the addition of corn starch to the PVOH matrix increases the degradation rate of the sample. The degradation process increases as the corn starch content increases. They produced films with the following composition ratio of PVOH:corn starch: 100/0, 70/30,60/40,50/50, and 30/70. The authors observed that all of the films in soil and compost degraded rapidly in the first 7 days. This rapid degradation was due to the composting process, which occurred in two main stages: an active composting stage (the temperature rose and remained elevated) and a curing period. The 30/70 PVOH:corn starch sample showed the highest weight loss while pure PVOH showed the lowest weight loss over time. This finding was attributed to the corn starch content in the film because corn starch is more biodegradable than pure PVOH [31]. Despite the fact that the polymeric base used in this study was demonstrably biodegradable, the compounds added, such as MaAh, N-Z and CN, changed the interactions of the polymeric chain, which would be influenced in the biodegradable properties of the matrix. Several active packagings have been developed in biodegradable matrices, but studies about these properties were not done. So, for future works, this study recommends the biodegradability properties of active and composite films.

\section{Conclusions}

Pollution problems drive a replacement of plastic products with eco-friendly biodegradable films. However, good performance is important for the application of these films, which reinforces the need for scientific research on this topic. In this work, the molecular interactions of biodegradable active CS-PVA blends plasticized with GLY and incorporated with $\mathrm{CN}, \mathrm{N}-\mathrm{Z}$, and MaAh were investigated and correlated to thermal properties. The compounds interacted among themselves and the intensity of these interactions was influenced by the amounts added into the blends. The thermal stability varies slightly due to the amounts of the $\mathrm{CN}, \mathrm{N}-\mathrm{Z}$, and MaAh compounds. Therefore, these compounds can be used to improve mechanical properties and packaging functions without compromising thermal properties. Important observations were done; one of them was the fact that the MaAh ring probably opened and converted to maleic acid in order to participate in transesterification reactions. Furthermore, $\mathrm{CN}$ incorporation enhanced the crystallinity domains through the intermolecular spaces, as well as increased the molecular interaction within other compounds. This work observed heterogeneous distribution maps of the compounds along the films caused by interaction affinity and the film production procedure. Regarding the antimicrobial perspective, $\mathrm{N}-\mathrm{Z}$ and MaAh acted as antimicrobial agents against $P$. aeruginosa, $S$. aureus, $S$. Choleraesuis, and E. coli, inhibiting the microorganisms by contact and compound diffusion. Therefore, the CS-PVA blends plasticized with GLY and the compounds MaAh, CN, and N-Z added into them have great potential to be applied in several industrial fields as an alternative to non-biodegradable films, presenting great thermal and antimicrobial features.

Author Contributions: T.V.d.O. and C.C.P. conceptualized and planned the experiments. C.C.P. and N.d.F.F.S. picked up the resources and the funding acquisition. T.V.d.O. carried out the investigation. L.R.T., A.T.B. and M.M.d.O. planned and carried out the simulations. T.V.d.O., P.A.V.d.F., J.O.R.d.S., N.S.J. and R.R.A.S. performed the methodology. T.V.d.O. and P.A.V.d.F. performed the formal analysis and data curation. T.V.d.O. took the lead in writing, review and editing the original draft preparation. Also was responsible for the project administration. N.d.F.F.S. provided the supervision. All authors provided critical feedback and helped shape the research, analysis and manuscript. All authors have read and agreed to the published version of the manuscript.

Funding: This research was funded by the National Council of Scientific and Technological Development (CNPq), grant numbers 2018/150009, and São Paulo Research Foundation (FAPESP), grant numbers 2017/17628-3 and 2019/06842-0. 
Institutional Review Board Statement: Not applicable.

Informed Consent Statement: Not applicable.

Acknowledgments: The authors thanks CAPES, CNPq, FAPEMIG, and FINEP by the research financing; UNICAMP, Célio Pasquini and Cristiane Vidal, from the Institute of Chemistry, for the equipment availability.

Conflicts of Interest: The authors declare no conflict of interest. The funders had no role in the design of the study; in the collection, analyses, or interpretation of data; in the writing of the manuscript, or in the decision to publish the results.

Appendix A
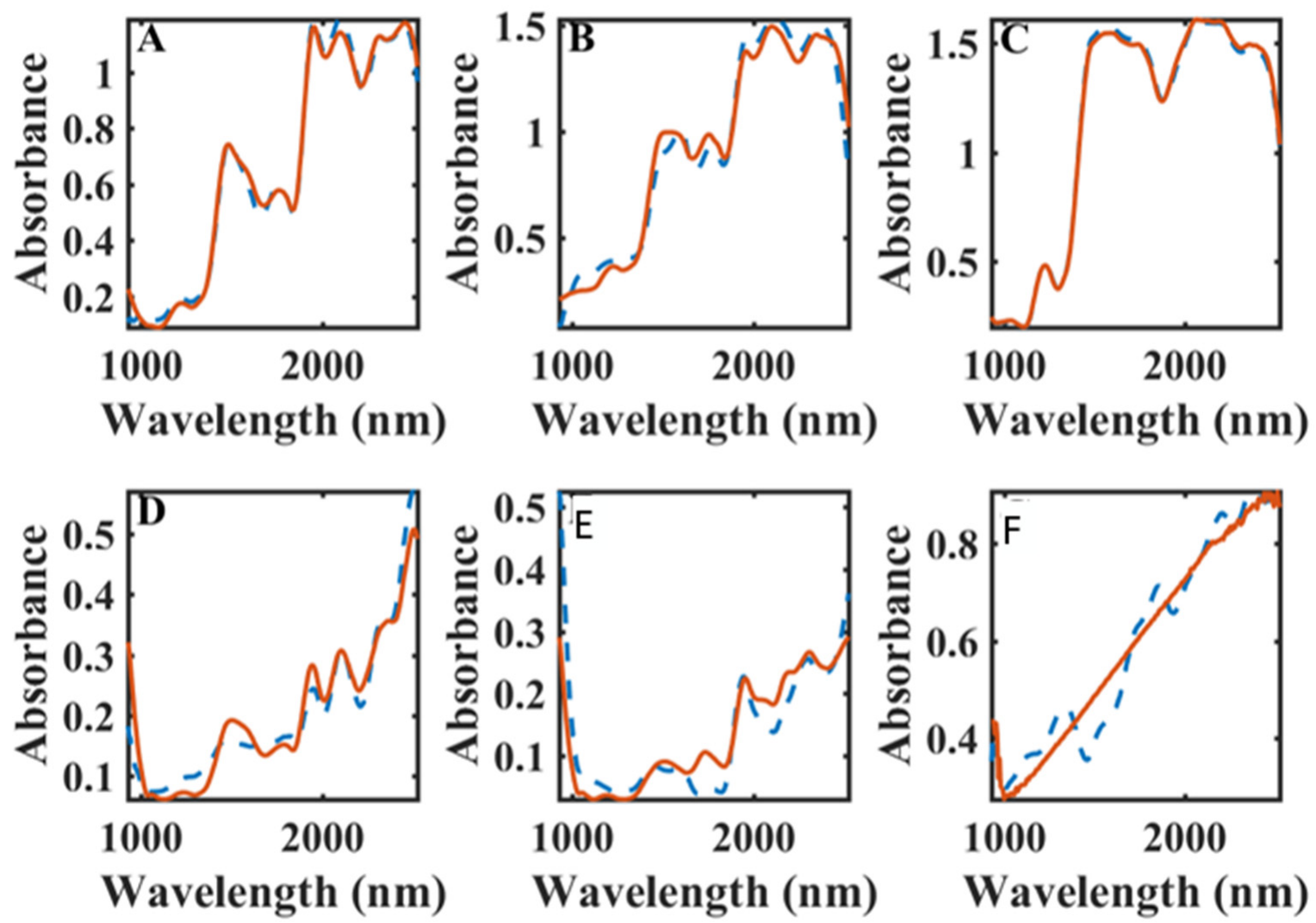

Figure A1. MCR-ALS-NIR spectra profile: (blue dashed lines) compared with standard spectra (red continuous line) and their correlation coefficient $\left(R^{2}\right)$ values for $(A)$ starch $\left(R^{2}=0.996\right),(B)$ PVA $\left(R^{2}=0.978\right),(C)$ GLY $\left(R^{2}=0.999\right),(D) C N\left(R^{2}=0.925\right),(E)$ $\mathrm{N}-\mathrm{Z}\left(\mathrm{R}^{2}=0.951\right)(\mathrm{F})$ Teflon for $\mathrm{T} 1(0.0 \%, 3.3 \%, 4.5 \%)$. 

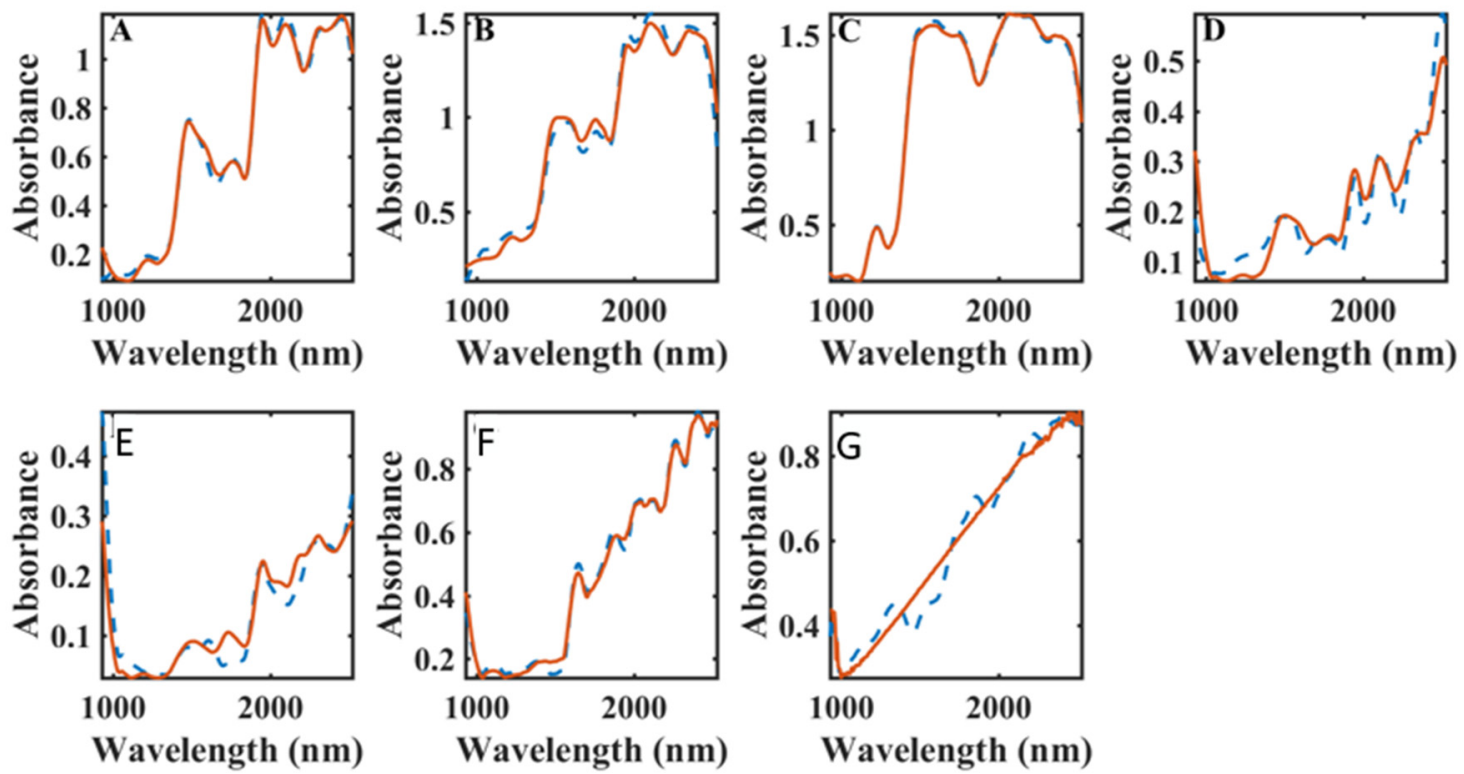

Figure A2. MCR-ALS-NIR spectra profile: (blue dashed lines) compared with standard spectra (red continuous line) and their correlation coefficient $\left(R^{2}\right)$ values for $(A)$ starch $\left(R^{2}=0.995\right),(B)$ PVA $\left(R^{2}=0.986\right),(C)$ GLY $\left(R^{2}=0.999\right),(D) C N$ $\left(R^{2}=0.896\right),(E) N-Z\left(R^{2}=0.859\right),(F)$ MaAh $\left(R^{2}=0.996\right)$, and $(G)$ Teflon $\left(R^{2}=0.968\right)$ for T6 $(6.3 \%, 3.3 \%, 4.5 \%)$ of MaAh, CN and $\mathrm{N}-\mathrm{Z}$ respectively.

\section{References}

1. Cho, S.Y.; Rhee, C.C. Mechanical properties and water vapor permeability of edible films made from fractionated soy proteins with ultrafiltration. LWT Food Sci. Technol. 2004, 37, 833-839. [CrossRef]

2. Almasi, H.; Ghanbargadeh, B.; Entegami, A.A. Physicochemical properties of starch-CMC nanoclay biodegradable films. Int. J. Biol. Macromol. 2010, 46, 1-5. [CrossRef]

3. Manson, J.A.; Sperling, L.H. Polymer Blends and Composites; Springer Science \& Business Media: New York, NY, USA, 1977; p. 513

4. Avella, M.; De Vlieger, J.J.; Errico, M.E.; Fischer, S.; Vacca, P.; Volpe, M.G. Biodegradable starch-clay nano composite films for food packaging applications. Food Chem. 2005, 3, 467-474. [CrossRef]

5. Imam, S.H.; Gordon, S.H.; Burgess-Cassler, A.; Greene, R.V. Accessibility of starch to enzymatic degradation in injection-injectionmoulded starch-plastic composites. J. Environ. Polym. Degrad. 1995, 3, 107-113. [CrossRef]

6. Pegoretti, A.; Dorigato, A.; Penati, A. Tensile mechanical response of polyethylene-Clay nanocomposites. Express Polym. Lett. 2007, 1, 123-131. [CrossRef]

7. Siregar, J.P.; Jaafar, J.; Cionita, F.; Jie, C.C.; Bachtiar, D.; Rejab, M.R.M.; Asmara, Y.P. The effect of maleic anhydride polyethylene on mechanical properties pineapple leaf fibre reinforced polylactic acid composites. Int. J. Precis. Eng. Manuf. Green Technol. 2019, 6, 101-112. [CrossRef]

8. Habibi, Y.; Lucia, L.A.; Rojas, O.J. Cellulose nanocrystal: Chemistry, Self-assembly and applications. Chem. Rev. 2010, 110, 3479-3500. [CrossRef]

9. Lim, W.S.; Ock, S.Y.; Park, G.D.; Lee, W.; Lee, M.H.; Park, H.J. Heat-sealing property of cassava starch film plasticized with glycerol and sorbitol. Food Packag. Shelf Life 2020, 26, 100556. [CrossRef]

10. Bahrami, A.; Delshadi, R.; Assadpour, E.; Jafari, D.M.; Willians, L. Antimicrobial-loaded nano carriers for food packaging applications. Adv. Colloid Interface Sci. 2020, 278, 102140. [CrossRef]

11. Mulders, J.W.M.; Boerrigter, I.J.; Rollema, H.S.; Siezen, R.J.; Vos, W.M. Identification and characterisation of the lanbiotic Nisin Z, a natural Nisin variant. Eur. J. Biochem. 1991, 201, 581-584. [CrossRef]

12. Lee, J.M.; Jang, W.J.; Lee, E.-W.; Kong, I.-S. B-glucooligosaccharides derived from barley B-glucan promote growth of lactic acid bacteria and enhance nisin Z secretion by Lactococcus lactic. LWT 2020, 122, 109014. [CrossRef]

13. Oliveira, T.V.; de Freitas, P.A.D.; de Pola, C.C.; da Silva, J.O.R.; Diaz, L.D.A.; Ferreira, S.O.; Soares, N.d.F.F. Development and optimization of antimicrobial active films produced with a reinforced and compatibilizem biodegradable polymers. Food Packag. Shelf Life 2020, 24, 100459. [CrossRef]

14. Asensio, R.C.; Moya, M.S.A.; de la Roja, J.M.; Gómez, M. Analytical characterization of polymers used in conservation and restoration by ATR-FTIR spectroscopy. Anal. Bioanal. Chem. 2009, 395, 2081-2096. [CrossRef]

15. Terra, L.R.; Roque, J.V.; Pola, C.C.; Gonçalves, I.M.; Soares, N.d.F.F.; Teófilo, R.F. Study of chemical compound spatial distribution in biodegradable active films using NIR hyper spectral imaging and multivariate curve resolution. J. Chemom. 2019, 34, 1-15. 
16. Vidal, M.; Amigo, J.M. Pre-processing of hyperspectral images. Essential steps before image analysis. Chemom. Intell. Lab. Syst. 2012, 117, 138-148. [CrossRef]

17. Moraes, A.R.F.; Pola, C.C.; Bilk, A.P.; Yamashita, F.; Tronto, J.; Medeiros, E.A.A.; Soares, N.d.F.F. Starch, cellulose acetate and polyester biodegradable sheets: Effect of composition and processing conditions. Mater. Sci. Eng. C 2017, 78, 932-941. [CrossRef]

18. Garcia, P.S.; Grossmann, M.V.E.; Shirai, M.A.; Lazaretti, M.M.; Yamashita, F.; Muller, C.M.O.; Mali, S. Improving action of citric acid as compatibilizer in starch/polyester blown films. Ind. Crop Prod. 2014, 52, 305-312. [CrossRef]

19. ASTM D882. Standard Test Method for Tensile Properties of Thin Plastic Sheeting; ASTM International: West Conshohocken, PA, USA, 2009.

20. CLSI. Antimicrobial Susceptibility Testing Standards; Clinical and Laboratory Standards Institute: Pittsburgh, PA, USA, 2012.

21. Olivato, J.B.; Grossmann, M.V.E.; Yamashita, F.; Nobrega, M.M.; Scapin, M.R.S.; Eliras, D.; Pessan, L.A. Compatibilisation of starch/poly(butylene adipate coterephthalate) blends unblown films. Int. J. Food Sci. Technol. 2011, 46, 1934-1939. [CrossRef]

22. Gupta, A.P.; Kumar, V.; Sharma, M. Formulation and Characterization of biodegradable packaging film derived from potato starch \& LPDE grafted with maleic anhydride-LDPE composition. J. Polym. Environ. 2010, 18, 489-491.

23. Tedeschi, G.; Guzman-Puyol, S.; Ceseracciu, L.; Benitez, J.J.; Cataldi, P.; Bisset, M.; Heredia, A.; Athanassiou, A.; Heredia-Guerrero, J.A. Sustainable, high-barrier polyaleuritate/nanocellulose biocomposites. ACS Sustain. Chem. Eng. 2020, 29, 10682-10690. [CrossRef]

24. Mandal, A.; Chakrabarty, D. Studies on the mechanical, thermal, morphological and barrier properties of nanocomposites based on poly(vinyl alcohol) and nanocellulose from sugarcane bagasse. J. Ind. Eng. Chem. 2014, 20, 462-473. [CrossRef]

25. Rahman, W.A.; Sina, L.T.; Rahmat, A.R.; Samad, A.A. Thermal behavior and interactions of cassava starch filled with glycerol plasticized polyvinyl alcohol blends. Carbohydr. Polym. 2010, 81, 805-810. [CrossRef]

26. Pola, C.C.; Moraes, A.R.F.; Silva, C.R.; Menezes, E.G.T.; Mendes, F.Q.; Guimarães, I.C.; Oliveira, I.R.N.; Dores, M.T.; Monteiro, P.S. Ciência de tecnologia de alimentos: sustentabilidade, desafio e inovação. Rio Paranaíba 2017, 1, 205-228.

27. Kuwano, K.; Tanaka, N.; Shimizu, T.; Nagatoshi, K.; Nou, S.; Sonomoto, K. Dual antibacterial mechanism of Nisin Z against Gram-positive and Gram-negative bacteria. Int. J. Antimicrob. Agents 2005, 26, 396-402. [CrossRef] [PubMed]

28. Canevarolo, S.V. Ciência de Polímeros: Texto Básico Para Tecnolólogos e Engenheiros, 2nd ed.; Artliber Editora: Sao Paulo, Brazil, 2006.

29. Zhang, J.F.; Sun, X. Mechanical properties of poly(lactic acid)/starch composites compatibilized by maleic anhydride. Biomacromolecules 2004, 5, 1446-1451. [CrossRef]

30. Razavi, R.; Tajik, H.; Moradi, M.; Molaei, R.; Ezati, P. Antimicrobial, microscopic and spectroscopic properties of cellulose paper coated with chitoman sol-gel solution formulated by epsilon-poly-L-Lysine and its application in active food packaging. Carbohydr. Res. 2020, 489, 107912. [CrossRef] [PubMed]

31. Azahari, N.A.; Othman, N.; Ismail, H. Biodegradation studies of polyvinyl alcohol/corn starch blend films in solid and solution media. J. Phys. Sci. 2011, 22, 15-31. 